\title{
The fatty acid profile of meat of suckling lambs from ewes fed rapeseed and linseed*
}

\author{
B. Borys ${ }^{1}$, A. Borys ${ }^{2}$ and J.J. Pająk ${ }^{3}$ \\ ${ }^{I}$ National Research Institute of Animal Production, Department of Animal Genetic and Breeding \\ Experimental Station Koluda Wielka, 88-160 Janikowo, Poland \\ ${ }^{2}$ Meat and Fat Research Institute \\ Jubilerska 4, 04-190 Warsaw, Poland \\ ${ }^{3}$ The Kielanowski Institute of Animal Physiology and Nutrition, Polish Academy of Sciences \\ 05-110 Jabłonna, Poland
}

\begin{abstract}
Two groups of 6 ewes, each suckling a single ram lamb, were fed diets with $73 \%$ forage and $27 \%$ concentrate. In the experimental group, part of the concentrate was replaced by $100 \mathrm{~g}$ rapeseed and $50 \mathrm{~g}$ linseed. Lambs were slaughtered at 70 days of age (body weight about $22 \mathrm{~kg}$ ) and their leg muscles, M. adductor and M. semitendinosus were taken for estimation of chemical composition and fatty acid profile. It was found that the rapeseed and linseed supplement had a beneficial effect on the fatty acid profile, especially CLA, and increased the content of fat in milk. The change in milk composition influenced the quality of lamb meat only to a small extent. A reduced content of intramuscular fat and increased proportion of $n$-3 PUFA were found.
\end{abstract}

KEY WORDS: ewes, oilseed, lambs, meat, CLA, fatty acids

\section{INTRODUCTION}

Studies exploring the effect of diet composition on the fatty acid profile of ruminant milk and meat, designed to improve their health benefits, intensified when conjugated linoleic acid (CLA) was shown to have some anticarcinogenic and antiatherosclerotic properties (Parodi, 1999).

The composition of sheep diets is one of the most important factors affecting the quantity, but especially the quality of compounds deposited in intramuscular and depot fat. It was found that the ratio of saturated (SFA) to mono- (MUFA) and

\footnotetext{
* This research was conducted as part of National Research Institute of Animal Production statutory activity, Project No. 2203.2

${ }^{1}$ Corresponding author: e-mail: izzzdkw@by.onet.pl
} 
polyunsaturated (PUFA) fatty acids can be altered, and the CLA content of milk and meat can be increased by supplementing ruminant diets with feeds high in linoleic acid (Dhiman et al., 2000).

The aim of this study was to determine the effect of supplementing the diets of suckling ewes with rapeseed and linseed on the CLA content and fatty acid profile of milk, and on the CLA content and fatty acid profile of suckling lambs' meat.

\section{MATERIAL AND METHODS}

Two groups of 6 ewes feeding a single ram lamb were fed diets of similar nutritive value, containing $73 \%$ forage and $27 \%$ concentrate. In the experimental group (RL), concentrate was partly replaced by $100 \mathrm{~g}$ full-fat rapeseed and 50 $\mathrm{g}$ linseed. In both groups, lambs from 3 weeks of age were fed ad libitum with meadow hay and concentrate mixture.

Milk samples taken for 3 days in the $8^{\text {th }}$ week of lactation from the morning and evening milking were analysed for DM, protein and fat using MilkoScan equipment, as well as for cholesterol content and fatty acid profile by gas chromatography.

Lambs were slaughtered at 70 days of age at an average body weight of $21.7 \pm 3.9 \mathrm{~kg}$ and samples of $M$. adductor and M. semitendinosus were taken for analysis. Dry matter, protein and ether extract were estimated in M. adductor, and the fatty acid profile and cholesterol content in intramuscular fat extracted from $M$. semitendinosus. The cholesterol content was determined by gas chromatography (HP 5890 sII with column HP-1), and the fatty acid profile using a HP 6890 chromatograph with an Rtx-2330 column (Kramer et al., 1997).

The results were analysed statistically using Statistica 6.0 PL software.

\section{RESULTS AND DISCUSSION}

The protein and cholesterol contents in experimental ewes' milk were lower (by 20 and 15\%, respectively) than in the milk of control ewes (Table 1).

The content of fat (by 48\%) and especially CLA (by 82\%) in the milk of RL ewes was increased, which was due to the higher proportion of this component in milk fat (by 22\%) than in group C, and higher fat content. The dietary supplement of rapeseed and linseed caused some beneficial changes in the fatty acid profile of milk as it increased the UFA:SFA ratio and the proportion of $n-3$ PUFA by $9 \%$. Changes in the fatty acid profile were of a similar nature, but were not as pronounced as in the experiment of Borys et al. (2005), when full-fat rapeseed was added to diets for suckling ewes. 
It was found that the content of intramuscular fat decreased by $14 \%$ and CLA content decreased by $11 \%$ in lambs from the experimental group (Table 2 ). The difference in the CLA level was due to the lower fatness of muscles of RL lambs, because the proportion of this component in intramuscular fat was similar. Daily CLA consumption in milk was 158 and $365 \mathrm{mg}$ in the control and experimental groups, respectively.

Table 1. Milk composition

\begin{tabular}{lcc}
\hline \multirow{2}{*}{ Composition } & \multicolumn{2}{c}{ Feeding group } \\
\cline { 2 - 3 } Chemical components, $g / 100$ g of milk & $\mathrm{C}$ & $\mathrm{RL}$ \\
$\quad$ dry matter & 17.42 & 17.56 \\
protein & 4.97 & 4.96 \\
fat & 6.00 & 8.90 \\
cholesterol, mg & 255.5 & 216.2 \\
CLA, mg & 29.4 & 53.4 \\
Fatty acid profile, g/100 g offat & & \\
SFA & 66.40 & 63.90 \\
UFA & 33.32 & 35.16 \\
UFA:SFA & 0.51 & 0.55 \\
MUFA & 28.73 & 30.46 \\
PUFA & 4.59 & 4.70 \\
PUFA:SFA & 0.07 & 0.07 \\
n-3 & 1.10 & 1.20 \\
n-6:n-3 & 2.64 & 2.33 \\
CLA & 0.49 & 0.60 \\
\hline
\end{tabular}

Table 2. Chemical composition of lamb muscular tissue and fatty acid content in intramuscular fat

\begin{tabular}{lrrr}
\hline \multirow{2}{*}{ Composition } & \multicolumn{2}{c}{ Group $(\mathrm{n}=6)$} & \multirow{2}{*}{ SEM } \\
\cline { 2 - 3 } & $\mathrm{C}$ & $\mathrm{RL}$ & \\
\hline Muscular tissue components, g/100 g of tissue & 24.33 & 24.03 & 0.20 \\
dry matter & 19.05 & 19.18 & 0.20 \\
protein & 2.72 & 2.33 & 0.17 \\
$\quad$ fat & 66.9 & 67.1 & 1.38 \\
$\quad$ cholesterol, mg & 12.0 & 10.7 & 1.74 \\
CLA, mg & & & \\
Fatty acids, g/100 g of intramuscular fat & 40.95 & 39.98 & 0.88 \\
SFA & 58.05 & 59.47 & 0.89 \\
UFA & 1.44 & 1.49 & 0.05 \\
UFA:SFA & 37.80 & 38.23 & 0.83 \\
MUFA & 20.28 & 21.22 & 1.59 \\
PUFA & 0.51 & 0.54 & 0.05 \\
PUFA:SFA & 3.02 & 3.48 & 0.23 \\
n-3 & 5.15 & 4.65 & 0.19 \\
n-6:n-3 & 0.45 & 0.45 & 0.05 \\
CLA & & & \\
\hline SEM - & &
\end{tabular}

SEM - standard error mean

The decreased content of intramuscular fat in the muscles of suckling lambs from the experimental group, observed both here and in an earlier experiment (Borys et al., 2005) can be attributed to the much higher content of fat and CLA (exogenous for suckling lambs) in the milk of ewes supplemented with full-fat rapeseed and linseed (or rapeseed only), which slows down the process of fat synthesis in animal bodies (Azain, 2004). 
It seems that CLA deposition in different muscles of the leg is similar. A similar tendency was noted by Czauderna et al. (2004), in which a 5\% linseed oil supplement to diets of weaned lambs fattened to $30 \mathrm{~kg}$ body weight reduced CLA in $M$. biceps femoris by $14 \%$ in relation to the control lambs.

\section{CONCLUSIONS}

The use of full-fat rapeseed and linseed to feed suckling ewes caused a slight beneficial change in the fatty acid profile and a marked increase in the content of fat, especially CLA, in ewe milk. The change in milk composition had little effect on meat quality of suckling lambs. Lower fatness, decreased CLA content and a beneficial change in the profile of fatty acids in intramuscular fat, as reflected in a higher proportion of $n-3$ PUFA, were found.

\section{REFERENCES}

Azain M.J., 2004. Role of fatty acids in adipocyte growth and development. J. Anim. Sci. 82, 916 - 924

Borys B., Pająk J.J., Borys A., 2005. The effect of rapeseed fed to suckled ewes on the fatty acid profile of lamb meat. J. Anim. Feed Sci. 14, Suppl. 1, 231-234

Czauderna M., Kowalczyk J., Niedźwiedzka K.M., Wąsowska I., Pająk J.J., Bulska E., Ruszczyńska A., 2004. The effect of linseed oil and selenium on the content of fatty acids and some elements in the liver and selected tissues of sheep. J. Anim. Feed Sci. 13, Suppl. 2, 105-108

Dhiman T.R., Satter L.D., Pariza M.W., Galli M.P., Albright K., Tolosa M.X., 2000. Conjugated linoleic acid (CLA) content of milk from cows offered diets rich in linoleic and linolenic acid. J. Dairy Sci. 83, 1016-1027

Kramer J.C.K., Fellner V., Dugan M.E.R., Sauer F.D., Mossoba M.M., Yurawecz M.P., 1997. Evaluation acid and base catalysts in the methylation of milk and rumen fatty acids with special emphasis on conjugated dienes and total trans fatty acids. Lipids 32, 1219-1228

Parodi P.W., 1999. Conjugated linoleic acid and other anticarcinogenic agents of bovine milk fat. J Dairy Sci. 82, 1339-1349

\section{STRESZCZENIE}

\section{Profil kwasów tluszczowych mięsa jagniąt ssących matki otrzymujące w dawce nasiona rzepaku i Inu}

Dwie grupy po 6 matek karmiących jedynaka tryczka żywiono dawkami o podobnej zawartości białka i energii. W grupie doświadczalnej część paszy treściwej zastąiono $100 \mathrm{~g}$ nasion rzepaku i 50 g nasion lnu. Jagnięta ubito w 70 dniu życia i pobrano mięśnie udźca do oznaczenia składu chemicznego i profilu kwasów tłuszczowych. Stwierdzono, że dodatek nasion rzepaku i lnu spowodował niewielką korzystną zmianę profilu kwasów tłuszczowych oraz wyraźny wzrost zawartości tłuszczu, a zwłaszcza CLA, w mleku matek. Zmiana składu mleka w niewielkim stopniu wpłynęła na jakość mięsa jagniąt. Stwierdzono jedynie zmniejszenie zawartości tłuszczu śródmięśniowego oraz zwiększenie udziału kwasów tłuszczowych z grupy PUFA n-3. 